\title{
Agriculture of the Republic of Uzbekistan after the peak of the pandemic
}

\author{
Bakhodir Sultanov ${ }^{1, *}$, Lochinbek Amirov ${ }^{1}$, Mavluda Askarova ${ }^{1}$, Barna Rakhmankulova ${ }^{2}$, \\ and Maftuna Tosheva ${ }^{2}$ \\ ${ }^{1}$ Tashkent State University of Economics, 49 Uzbekistan street, 100003, Tashkent, Uzbekistan \\ ${ }^{2}$ Tashkent institute of irrigation and agricultural mechanization engineers, 39, Kari Niyazov street, \\ 100000, Tashkent, Uzbekistan
}

\begin{abstract}
When studying the topic, the author analyzes the implementation of reforms and their impact on the development of the agricultural sector of the Republic of Uzbekistan. Special attention is paid to the pandemic crisis that has affected all spheres of the economy and the life of the population. The importance of the actions taken by the state in relation to the improvement of the agricultural sector, not only through the production of agricultural raw materials, but also in other ways, is revealed. One of these ways is the production of products that can compete on the world market, the production of semi-finished products, and others. Methods of analysis, synthesis, grouping, observation, and deduction were used in the study of the material. Using these methods, the authors were able to come to a better conclusion, and make suitable conclusions and suggestions. In conclusion, the ways to improve the efficiency of agricultural production, through the introduction of resource-saving technologies, innovative technologies, and especially the removal of state attention to the agricultural sector, are revealed. The article also focuses on the state of agriculture during and after the pandemic, and compares it with other countries of the world. The authors made proposals that are most suitable for the development of agriculture, ensuring food security and independence of the population.
\end{abstract}

\section{Introduction}

The people of the Republic of Uzbekistan have been proficient in the art of cultivating agricultural land since ancient times, and the climatic conditions of the Republic have contributed to this. Under the climatic conditions of Uzbekistan, it is possible to cultivate fresh fruits, fruits and vegetables, berries, in huge quantities and assortment, meeting the needs of the population within the country, and creating competition in the foreign market. Against the background of abundant yields, enterprises for the processing of agricultural products are being created. They are successfully functioning and are even included in the list of major global producers (tomato paste, dried fruits, dried vegetables) [1].

Prior to the acquisition of Independence, the agriculture of the Republic of Uzbekistan underwent great difficulties, and its potential was not fully revealed. The reason was

\footnotetext{
*Corresponding author: sb.i.1@mail.ru
} 
monoculture; the predominant amount of fertile land was given for growing raw cotton [2]. Another reason was the lack of a system that stimulates the cultivation and production of agricultural products, since all farms carried out their activities collectively, without a goal and motivation for the development of this sector.

After gaining independence, the Republic of Uzbekistan firmly decided to diversify agriculture, to move away from the orientation towards cotton monoculture. It took a long time, and until now Uzbekistan does not stop to improve the agricultural sector. [3]

Table 1. Stages of agricultural formation of the Republic of Uzbekistan

\begin{tabular}{|c|c|}
\hline Year & Events \\
\hline 1991-1993 & $\begin{array}{l}\text { The legislative and legal framework and their implementation have been carried } \\
\text { out and developed. During this period, a regulatory and legal framework was } \\
\text { developed to ensure denationalization and privatization, as well as the formation } \\
\text { of a class of entrepreneurs and agricultural producers. In essence, the laws of the } \\
\text { Republic of Uzbekistan "On Land", "On Property", "On Lease", "On } \\
\text { Cooperation", "On Denationalization and Privatization", "On Entrepreneurship" } \\
\text { and others were adopted. Privatization and denationalization of livestock farms, } \\
\text { transfer of small orchards and vineyards to the private sector contributed to the } \\
\text { development of small commodity producers in the countryside, who replenished } \\
\text { the market with food products. The main distinguishing feature of the country's } \\
\text { agrarian food policy at that time was the pursuit of an active social policy and } \\
\text { the protection of vulnerable segments of the rural population. }\end{array}$ \\
\hline 1995-1998 & $\begin{array}{l}\text { Formation of the necessary legislative and legal norms, where special attention } \\
\text { was paid to financial policy, reduction of ineffective subsidies and subsidies } \\
\text { from the budget, implementation of a tax policy that provides incentives for food } \\
\text { producers, improvement of the banking system, orderliness of the pricing } \\
\text { system, and subsequently an increase in purchase prices for food products them } \\
\text { to the level of world prices. At the same time, programs and strategies for the } \\
\text { development of farms and dekhkans, private entrepreneurs and small and } \\
\text { medium-sized businesses were adopted, the main purpose of which was to } \\
\text { provide food for the population. }\end{array}$ \\
\hline $1999-2007$ & $\begin{array}{l}\text { Decisions and a concept for the development of farms and dekhkans were } \\
\text { adopted, the system of lease relations was improved, measures were taken to } \\
\text { deepen economic reforms in horticulture and viticulture. }\end{array}$ \\
\hline $2008-2016$ & $\begin{array}{l}\text { A number of decisions have been made on the food problem associated not only } \\
\text { with the increase in food production, but also with the development of strategies } \\
\text { for the rational use of food resources, the focus of increasing which should be } \\
\text { the qualitative and quantitative aspects of human nutritional needs. }\end{array}$ \\
\hline $2017-2020$ & $\begin{array}{l}\text { Significant food reserves are being formed, problems of water resources } \\
\text { management and their efficient use are being solved, drainage systems } \\
\text { reconstruction and irrigation systems improvement }\end{array}$ \\
\hline $2020-2030$ & $\begin{array}{l}\text { The "Strategy for the Development of Agriculture of the Republic of Uzbekistan } \\
\text { for } 2020-2030 \text { " was approved, which is based on a radical improvement of state } \\
\text { policy, the purpose of which is to increase the competitiveness of the agro-food } \\
\text { sector. }\end{array}$ \\
\hline
\end{tabular}

\section{Methods}

The object of the methodology is the agrarian sphere, as it includes agricultural organizations, farms, and other farms. The main methods are analysis, synthesis, deduction, grouping, 
comparison, selection method. Research methods are aimed at improving the efficiency of the functioning of the object of study, as in other areas, the goal is to increase output, and maximize profits. All methods interfere with the external and internal environment. [4-5]

\section{Results}

The agriculture of Uzbekistan is developing steadily from year to year, and shows good indicators. The sown area for 2020 amounted to 3373.1 thousand hectares, agricultural products 249754.5 billion soums, of which crop production 123556.0 billion soums, livestock products 126198.5 billion soums. Thus, the growth rate of agricultural production as a whole amounted to 102.8 in relation to the previous year. [6]

At the end of 2019, 80 thousand farms, 53 thousand dekhkan farms, 152 agricultural clusters in horticulture, 144 in grain growing, 93 clusters in cotton were operating in the Republic of Uzbekistan.

Covid-19 suddenly hit the whole world. In 2020, the pandemic caused an economic downturn, with the number of hungry people increasing by at least 83 million. Of all the operating sectors of the economy, the agrarian sector received the least damage. Imports and exports of food products suffered. There was a failure in the chain of food delivery to the population, and bringing raw materials to farms. But the countries tried to ensure internal food security, as did Uzbekistan. Many countries had a stock of food products, such as grain, so food prices did not change much, and the population did not particularly feel the impact of the pandemic.

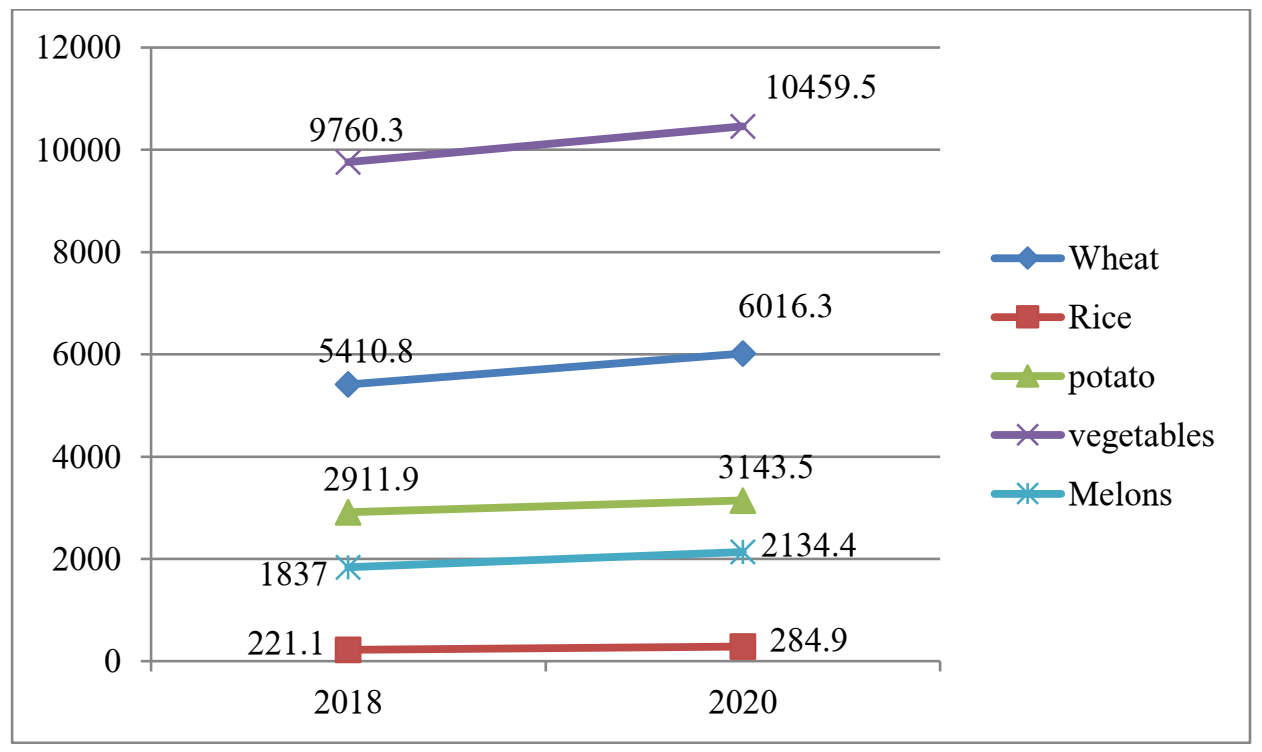

Fig. 1. Indicators of the main crops of the Republic of Uzbekistan for 2018 and 2020, thousands of tons.

As shown in Figure 1, the pandemic did not result in significant losses in agriculture. The state immediately took all the necessary measures to ensure an uninterrupted supply of food to the population. 
The pandemic has caused great damage to the world's economy, and agriculture separately. In many countries of the world, the pandemic has brought many problems [7], such as:

- sharp jumps in food prices due to trade restrictions (export bans) and panic among the population

- reduced access to food due to a sharp decline in income for the middle and poor

- failures in the supply chain of raw materials, which led to a failure and affected the harvest

- economic downturn has led to a decline in domestic demand

- problems with repayment of loans

- stress, threat of agricultural support programs.

Unlike other states, whose economies have been affected by the pandemic, Uzbekistan maintains stability. In many countries, the agrarian sector has suffered losses due to a decrease in demand from residents as a result of reduced profits. In countries such as the United States, Germany, Italy, workers in the agricultural sector temporarily refused to work due to the panic associated with the pandemic. In the United States, the pandemic has cut revenues from its most lucrative business, growing corn, by $\$ 50-\$ 90$ per acre. In India, food prices have dropped by 20 percent.

The Republic of Uzbekistan not only actively fought against the development of the virus in the country, but also increased the volume of food products to meet all the needs of consumers, and tried with all its might to prevent a disruption in the export of food products in the world. The main blow to agriculture from the pandemic was the closure of catering establishments, such as restaurants, cafes, and so on. Smallholder farms were mostly affected, as food businesses were the main buyers of fresh agricultural products. The Government of the Republic of Uzbekistan adopted a Decree "On priority measures to mitigate the negative impact on the economy of the coronavirus pandemic and global crisis phenomena" [8]. The government used the resources of the agricultural sector to the maximum, to increase yields, to create jobs. The Republic of Uzbekistan not only actively fought against the development of the virus in the country, but also increased the volume of food products to meet all the needs of consumers, and tried with all its might to prevent a disruption in the export of food products. in the world. The main blow to agriculture from the pandemic was the closure of catering establishments, such as restaurants, cafes, and so on. Smallholder farms were mostly affected, as food businesses were the main buyers of fresh agricultural products. The Government of the Republic of Uzbekistan adopted a Decree "On priority measures to mitigate the negative impact on the economy of the coronavirus pandemic and global crisis phenomena" [8]. The government used the resources of the agricultural sector to the maximum, to increase yields, create jobs.

There are negative factors that affect the efficiency of land use:

- Water problems - lack of water resources, underdeveloped water management system, instability of water supply to consumers in all regions of the country, low level of technical condition of irrigation systems, losses during filtration during irrigation $[9,10]$

- Land resources - inefficient use of land resources, imperfection of land relations, lack of stable monitoring of the state of land

- Agro-technical rules - deviation from the norms of agro-technical cultivation of land, and the cultivation of crops.

\section{Discusion}

The increase in the share of the agricultural sector has a multiplier effect. According to research, a $\$ 1$ growth in agriculture will affect the growth of the rest of the economy by $\$ 1$ as well. But growth in the rest of the economy will not cause the same growth in agriculture, 
so a $\$ 1$ growth in the rest of the economy would only affect agricultural growth by only $\$ 0.18$. These multiplier farming patterns tend to occur in low-income countries because the bulk of the industrial (agro-processing) and service sectors (food marketing) are linked to agricultural performance. [11-12]

Labor productivity in agriculture also bears a chain character. Increasing labor productivity in agriculture leads to:

-provision of food security for the entire population, regardless of the type of their employment, thereby increasing the growth of the urban population

-reduces prices for food products, thereby reducing the nominal wages of the urban population. [13-14]

The fruits of the agricultural sector, as everyone knows, depends on natural and climatic conditions, using traditional technologies for cultivating land and obtaining food products, the costs will be related to production costs. The main thing here is not to forget about resource-saving technologies, which are very effective and create a beneficial effect on the agrocenosis, and do not harm fertility.

Resource conservation implies not only agro-technical measures, but also organizational, technical and technological measures, with a rational process of using resources based on the modernization of technological processes and the use of innovative methods. The use of resource-saving technologies increases the efficiency of economic activity, reduces costs, and increases the productivity of enterprises. [15]

In addition to using resource-saving technologies, it is effective to apply innovative technologies. The use of innovative technologies in the form of automation of agricultural activities increases yields and product quality, and reduces costs. The leaders in the world in the use of automated mechanisms in agriculture are the USA, China, India, Brazil, Japan. If you use automated complexes in agriculture, you can see the following picture:

- the cost of fuel and lubricants is reduced, the loss of water and electricity is reduced, thereby the efficiency of business processes increases by $50-70 \%$

- due to the automation of the main agricultural processes, losses during harvesting are reduced to $60-80 \%$

- increases productivity by 1.5 times

- Crop planting costs will be reduced by up to $80 \%$

Innovative technologies in agriculture include smart greenhouses, smart farms, monitoring the use of agricultural machinery, sensors for the preservation of raw materials, smart storage, automation of irrigation, electronic trading platforms, various smart technical devices, soil sensors, various automated assistants performing various processes (harvesting, weed removal and so on).

\section{Conclusions}

The state supports the effective development of agriculture in the Republic of Uzbekistan. The "Strategy for the Development of Agriculture of the Republic of Uzbekistan for 20202030" was approved, the purpose of which is to improve state policy, increasing the competitiveness of the agricultural sector. The strategy was based on:

- food security of the population

- improving and shaping the climate for agro-entrepreneurship and the value chain

- reducing the share of government intervention in the management of agricultural production and attracting investment

- rational use of natural resources, improving the state of the environment

- improving state governance systems

- diversification of costs in support of the agricultural sector 
- development of science for the development of agriculture and professional development of specialists

- improvement of rural infrastructure

- reliable statistics

The study of the topic led us to the following conclusions-recommendations that will help the agricultural sector to develop more efficiently, despite the influence of factors from the outside:

- Integrated water resources management needs to be improved by involving stakeholders and linking this to land management

- Institutional improvement in the agricultural sector, active implementation of agricultural reforms, development of legal mechanisms for regulating water-land relations

- Planning the socio-economic picture, and long-term development of the agricultural sector

- Management of the agro-industrial complex, as a single organizational and legal object, increasing the role of the Ministry of Agriculture and the Ministry of Water Resources of the Republic of Uzbekistan, as organizers and coordinators of the functions of the Agroindustrial complex

- Combination of large, medium, small dekhkans and private farms and enterprises of various forms of ownership, and maintaining an effective division of production between forms of management

- Supporting the level of investment in the agricultural sector using scientific and technological progress and innovation

- Development of cooperative forms and links between industry and agriculture

- Active implementation of "smart" technologies

The implementation of the proposed measures contributes to the development of the agricultural sector in the production of food products. As a result of the implementation of the proposed measures, it will be possible to develop processing related industries, create tens of thousands of new jobs, increase the income of the rural population, improve the quality of food supply in a full range and volume, increase exports, which will affect macroeconomic stability and economic growth of the Republic of Uzbekistan.

\section{References}

1. N. A. Ashurmetova, The current state and development strategy of the agrarian sector of the Republic of Uzbekistan Scientific journal "Science without Borders", 42, 18-27 (2020)

2. D. N. Saidova, Issues of ensuring food security and increasing the competitiveness of agriculture in the region, Journal of the Bulletin of Science and Education, 14(68), 4244 (2019)

3. G. G. Dustmurodov, I. O. Yunusov, U. K. Ahmedov, Sh. M. Murodov, S. T. Iskandarov, The mechanism for the development of public-private partnerships in agriculture (on the example of the Republic of Uzbekistan) E3S Web of Conferences TPACEE-2020, 224, 04042 (2020)

4. S. Babu, et al., Food policy reforms in Central Asia: setting the research priorities. International Food Policy Research Institute Workshop Proceedings, 22-65 (2000)

5. P. Bloch, Agrarian reform in Uzbekistan and other Central Asian countries. University of Wisconsin Land Tenure Center Working Papers, 49, 4-18 (2002)

6. stat.uz - official website of the State Committee of the Republic of Uzbekistan on statistics. https://stat.uz/uploads/docs/qishloq_xo'jaligi_dekabr_uz.pdf/ (Last accessed 10.01.2021) 
7. By the Decree of the President of May 7, 2018 "On additional measures to improve the mechanisms for introducing innovations in the industry and the economy"

8. Decree of the President of the Republic of Uzbekistan No. UP-5969 "On priority measures to mitigate the negative impact on the economic sectors of the coronavirus pandemic and global crisis phenomena" dated 03.19.

9. Z. Lerman, Land reform, farm structure, and agricultural performance in CIS countries. China Economic Review, 20, 316-326 (2009)

10. Z. Lerman, Agricultural development in Uzbekistan: the effect of ongoing reforms. Center for Agricultural Economic Research Discussion Paper, 7.08, 5-27 (2008)

11. Y. Mundlak, et al., Agricultural development: issues, evidence, and consequences. Policy Research Working Papers, 1811, 6-41 (1997)

12. D. Islamova, U. Kholiyorov, K. Dustmukhammad, F. Shafkarov, K. Numonov, The relevance of potato farming in the agricultural economy (on the example of the Republic of Uzbekistan) E3S Web of Conferences BFT-2020, 215, 02001 (2020)

13. COVID-19 global economic recession: Avoiding hunger must be at the centre of the economic stimulus. FAO (Rome, 2020) https://doi.org/10.4060/ca8800en

14. V. A. Tsvetkov, A. A. Shutkov, M. N. Dudin, N. V. Lyasnikov, Digital economy and digital technologies as a vector of strategic development of the national agro-industrial sector Bulletin of Moscow University. Series 6: Economics, 1, $45-64$ (2018) doi: 10.33051 / 0130-0105-2018-1-45-64 